\title{
A dimensão esquecida
}

\author{
A coletânea de Harrison e Huntington mostra o papel da cultura \\ sobre o desenvolvimento econômico e político, sobre as relações \\ de gênero e a promoção de mudanças. Os autores demonstram a \\ força e a influência dessa dimensão, que por muito tempo ficou \\ de fora das preocupações de gestores, políticos e economistas.
}

por Carlos Osmar Bertero FGV-EAESP

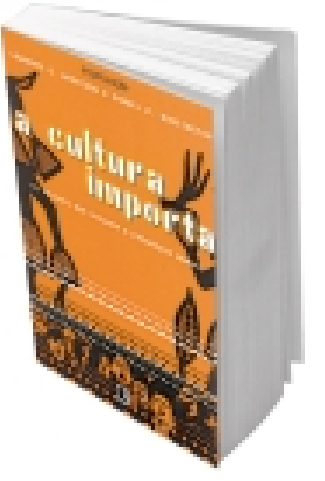

A cultura importa: os valores que definem 0 progresso humano Lawrence E. Harrison e Samuel P. Huntington (Orgs.) Record, 2002 cultura importa é formado por 22 trabalhos inéditos, distribuíd os em sete seções. 0 agrupamento é em função do tipo de impacto que a cultura pode causar. Há uma seção especial dedicada à "crise asiática", com capítulos envolven do valores asiáticos, os diversos caminhos de modernização quetêm atingido a Ásia e como fazer negócios naquele continente.

A seção mais longa é a dedicada ao desenvolvimento econômico. N ela encontramos sete capítulos de renomados autores, como David Landes, Jeffrey Sachs e Michael Porter. 0 que emerge é que a cultura tem importância definitiva para o desenvolvimento econômico. David Landes havia anteriormente se debruçado sobre a mesma questão, em seu livro Causas da riqueza e da pobreza das nações.

Todos os autores enunciam com clareza a importância da cultura e afirmam que há culturas que favorecem mais, outras menos e que al gumas podem até ser inibidoras do desenvolvimento econômico. 0 grande exemplo histórico é o próprio Ocidente, que, a partir do final da Idade Média, passou a se distanciar das demais culturas, atingindo o nível de ri- queza e desenvolvimento de que hoje desfruta.

Landes lembra que, na baixa Idade Média européia, a China e o mundo islâmico eram mais ricos, mais sofisticados e fonte de imitação pela Europa 0 cidental. 0 distanciamento do 0 cidente se deu graças a fatores culturais, como a liberdade para empreender, o respeito à instituição da propriedade privada, o individualismo e a instrumentalização da razão. Os argumentos de Landes em boa medida retomam os tópicos tratados na sociologia por Max Weber.

Por sua vez, Porter observa a importância da cultura nacional para que uma economia tenha empresas competitivas. Segundo ele, a competitividade de uma nação é determinada pela competitividade desuas empresas. 0 trabalho de Porter está voltado para demonstrar que o país de origem, ou aquele no qual a empresa tem sua sede, é que determina sua competitividade. Empresas que têm origem em economias e culturas mais competitivas, levarão suas características para ou tros países onde venham a operar.

A seção dedicada ao impacto da cultura sobre o desenvolvimento político con- 
tém três capítulos, um de Ronald Inglehart, outro de Francis Fukuyama e o terceiro de Seymour M. Lipset e Gabriel Salma Lenz, sobre corrupção, cultura e mercados. Essa seção é a que possivelmente contém os trabalhos de melhor qualidade acadêmica.

0 trabalho de Inglehart utiliza uma base de dad os do World Value Survey, que inclui 50 sociedades. Tal fonte usa a classificação de culturas enunciada por Samuel Huntington em seu texto 0 choque de civilizações e demonstra que existe uma clara associação entre regimes democráticos e desenvolvimento econômico. Todavia, isso não implica uma relação mecânica. Ou seja, dado o desenvolvimento econômico, segue se um desenvolvimento político na linha da democracia representativa. $N$ a verdade, formas de poder e regimes de governo que precedem um surto de crescimento econômico tendem a prevalecer ainda por algum tempo. 0 caso da China seria hoje o mais ilustrativo, na medida em que se tem um país que apresenta elevadas taxas de crescimento, mas que mantém um sistema político autoritário.

0 texto éoportuno por diversas razões. Durante toda a segunda metade do século XX o crescimento econômico foi tratado a partir de uma perspectiva quase que exclusivamente econômica. Atualmente se reconhece que a questão econômica é importante demais para ser entregue apenas aos economistas. Dessa forma, a retomada do debate, trazendo as perspectivas da antropologia, da história e de outras ciências sociais, tem como efeito imediato seu enriquecimento e a abertura de novas possibilidades de diálogo.

Quando se fazem análises culturais, uma questão particularmente delicada é a dos valores, o que toca no dilema tradicional das ciências sociais. No limite, até que ponto tais ciências podem ser vistas como apoiadas em juízos de fato e até que ponto se admite, ou mesmo se advoga, que elas envolvem obrigatoriamente juízos de valor? Falar sobre culturas e compará-las, relacioná-las com desenvolvimento econômico, político, social e questões de gênero equivalea julgar culturas, ou seja, a entrar em um universo claramente de valores. 0 pluralismo, bem como a hoje valorizada "correção política", impediria que se o fizesse.

Mas, na verdade, rodamos em círculos, porque mesmo os que advogam a chamada neutralidade científica ou o pluralismo, ao fazêlo, estão implicitamente adotando valores. Portanto, acho que não há razões para que se mantenha um falso pudor científico e se reconheça que de fato a cultura importa. Mesmo que estejamos "incorretos", estaremos em boa companhia no mundo das ciências sociais.

Carlos Osmar Bertero

Chefe do Depto. de Administração Geral e Recursos Humanos da FGV-EAESP

Ph.D. in Business Administration pela Cornell University

E-mail: cbertero@fgvsp.br 